believed to have segregated in immiscible liquid fractions.

The presidential address of Section $\mathrm{V}$ was given by Dr. B. P. Babkin, of McGill University, on "Antagonistic and Synergistic Phenomena in the Autonomic Nervous System". Most internal organs have a double nerve supply of which one is excitatory (sympathetic) and the other inhibitory (parasympathetic), that is, they work against each other. For the digestive glands, however, the parasympathetic works with the sympathetic, both giving stimulation. There are no true inhibitory nerves, and secretion is inhibited only through reducing the blood supply by vasoconstriction.

Dr. W. Rowan presented an invited review of investigations upon the factors influencing migration of birds, and outlined a new theory of the origin of speech. An important group of papers upon physiological characteristics of fishes which influence their distribution and their behaviour was presented by C. W. Andrews, E. C. and V. S. Black, J. S. Hart, and F. E. J. Fry, the last bringing forward notable general considerations regarding controlling and limiting factors in environment. Two papers by Kenneth Graham discussed certain fundamental aspects of the physiology of codling moth larvæ and described a new disease of black-headed budworms.

In the field of botany, five new species and two suggested new genera were reported among seed-borne fungi, and conifer-borne species of Tympanis were described. Dr. A. H. Hutchinson presented three papers giving original methods that are being applied to ecological studies in British Columbia forests. A study by Herbert Stern of pollen cells and pollen mother-cells at the time of division discovered an extraordinary increase in permeability. An investigation by Dr. William Leach of oxygen and nitrogen respiration provided interesting indications of oxidative anabolism in a number of germinating seeds, in various tissues with different food reserves, and in Aspergillus growing on media with different sugars.

Dr. Madge T. Macklin and Dr. Louise Hopkins reported a statistical study in children of two kinds of congenital nerve deafness which are hereditary and both dependent upon recessive genes. However, it appears that there is occasional departure from the rule that all children of parents who are both affected with the same recessive defect are affected. Dr. R. G. Sinclair discussed the reactions of mustard gas with cephalins such as phosphatidyl serine and phosphatidyl ethanolamine. The resultant compounds cannot be dispersed in water and their base-binding capacities are considerably lower than those of the corresponding lipids. Drs. S. D. Simpson, S. H. Zbarsky and $\mathrm{L}$. Young reviewed briefly their investigations of the toxicity and antidotal activity of British Anti-Lewisite (BAL), 2,3-dimercapto propanol, and of related thiols. These studies were greatly facilitated by the use of radioactive sulphur $\left(\mathrm{S}^{35}\right)$ which was incorporated in the compounds under investigation.

The officers of the Royal Society of Canada elected for 1946-47 were as follows : President, Dr. H. A. Innis, professor of political science in the University of Toronto; Vice-President, Dr. W. P. Thompson, professor of biology in the University of Saskatchewan; President, Section I, Pierre Daviault, Ottawa; President, Section II, Dr. Alexander Brady, associate professor of political science in the University of
Toronto ; President, Section III, Dr. E. L. Harrington, professor of physics in the University of Saskatchewan; President, Section IV, Dr. Bruce Rose, of the Department of Geology, Queen's University, Ontario ; President, Section V, Prof. J. R. Dymond, professor of systematic zoology in the University of Toronto.

\section{NATIONAL RESEARCH COUNCIL OF CANADA}

\section{A MEDICAL RESEARCH DIVISION}

\section{A} DIVISION of Medical Researeh has been established by the National Research Council of Canada to carry on work previously directed through the Associate Committee on Medical Research. Dr. J. B. Collip, director of the Research Institute of Endocrinology, McGill University, Montreal, chairman of the former Associate Committee, has been appointed director of the Division, and Dr. G. H. Ettinger, professor of physiology, Queen's University, Kingston, assistant director. A new Committee on Medical Research will advise on questions of policy and with respect to medical problems which should be investigated. Under the new organisation of this work, the National Research Council will continue to support medical research mainly in the existing medical schools and hospitals throughout Canada, rather than through the establishment of medical research laboratories and appointment of medical research workers under its own auspices. The general subject of medical research was sponsored by the National Research Council just before the War at the request of the Canadian Medical Association and the Royal College of Physicians and Surgeons. On the outbreak of war, the Associate Committee on Medical Research offered its services through the National Research Council to the Dominion Government for the coordination of war-time medical research.

Most of the war problems investigated by the Associate Committee on Medical Research were supervised by four subcommittees, all with members from the Services. The Subcommittee on Shock and Blood Substitutes (chairman, Dr. C. H. Best) directed researches through regional groups in Toronto and Montreal on the fundamental nature of shock, on the use of isinglass as a blood substitute, on the preparation, properties, storage and transportation of dried human blood serum, and on methods of preservation of whole blood and red blood cells. It acted as adviser to the Connaught Laboratories, the Canadian Red Cross Society, and the Department of Pensions and National Health, in the matter of preparation of dried serum, and to the Royal Canadian Army Medical Corps in the preparation of a film demonstrating the recognition and treatment of shock. It issued memoranda on the "Early Recognition and Treatment of Shock" and on the "Organization and Operation of a Blood Bank".

The Subcommittee on Infections (chairman, Dr. Duncan Graham) organised researches on the diagnosis and treatment of wounds infected with gas gangrene and other organisms, and pioneer experiments on the local application of sulphonamides. It supervised the production of typhus vaceine and Shiga toxoid, and made suitable recommendations to the Department of National Defence concerning their use. It instituted experiments on methods of 
production and use of penicillin. From its pilot plant in Toronto it supplied large quantities of penicillin to the Department of National Defence, and less amounts for civilians, until the commercial production in Canada was able to supply ordinary needs. It undertook the preparation of an influenza vaccine. It prepared recommendations for prevention of infection of wounds. It advised the Department of National Defence on questions of bacteriological significance as often as requested.

The Subcommittee on Surgery (chairman, Dr. Wilder D. Penfield) supervised researches through regional groups in Montreal, Toronto, London and Winnipeg, and through sections on burns, orthopædics, plastic surgery, surgical radiology, thoracic surgery, and traumatic injuries of the nervous system. These included investigations on the treat ment of burns; infected wounds and peripheral nerve injuries ; treatment of low-back pain with and without sciatica; use of penicillin; skin grafting ; bone grafting; facial prostheses; recognition of non-metallic foreign bodies by X-rays; and surgical problems of air transport of wounded.

The Subcommittee on Industrial Hygiene and Industrial Medicine (chairman, Dr. D. Y. Solandt) was concerned mainly with health problems in industries active in the manufacture of munitions and supplies.

The Associate Committee also provided the Department of National Defence with recommendations in respect of nutrition and prepared a memorandum on problems of nutrition in Canada, which was submitted to the Ministry of Food and the Medical Research Council in Great Britain.

In carrying out this programme of medical research, the Associate Committee had the co-operation and assistance of several hundred leading physicians and surgeons throughout Canada, who were keenly interested in this subject. Their able and willing contributions enabled the Committee to plan and direct medical research during the War on a high level of efficiency. Under the new arrangement the existing need for expansion can be met and continuity of research from year to year in selected fields will be provided for on a permanent basis.

\section{$161=$}

\section{NATIONAL INSTITUTE OF ECONOMIC AND SOCIAL RESEARCH}

\begin{abstract}
$\mathrm{T}$ HE annual report for 1944-45 of the National Institute of Economic and Social Research*, referring to/ hersteps taken to execute the research polic forlthe immediate post-war years outlined in the Af us report, refers to an inquiry into distributif n) for the planning, direction and organisation of theh Mr. Hugh Weeks is responsible as chairman of a small technical committee. A second step is the decision to start a study of the building industry, for which purpose Mr. I. Bowen has accepted an appointment as research associate. The further development of the Institute's research policy depends upon the availability of trained applied economists who possess the experience and maturity for handling
\end{abstract}

* National Institute of Economic and Social Research. Annual Report. 1944-45. Pp. 22. Publications and Programmes. Pp. 22. (London, 1945.) large-scale projects. With minor exceptions, there have been in Britain no trained economists coming from the universities for five years, while the demand for applied economists is not falling off with the end of the War. The year that has passed since the Institute's post-war research policy was outlined confirms the prediction then made that demands for guidance would be made on an unprecedented scale.

A joint exploratory committee has been set up with representatives of the Institute of Chartered Accountants to investigate the field of work in which account. ants and economists have a common interest and which would repay more detailed co-operative investigation. The first task of the committee is to explore the varying meanings and uses of terms such as 'income', 'expenditure', 'capital', 'saving', 'profit', 'loss', 'maintaining eapital intact', 'stock valuation', and so on. At the end of 1944 the Institute intimated to the universities its desire to devote certain accumu. lated funds to university research in economics and allied social sciences in the United Kingdom during the post-war transition period ; as a result it has been decided to adopt a scheme of senior research fellowships and grants-in-aid to operate over the next two years.

The second and third issues of the Register of Research in the Social Sciences were prepared and eirculated, the response to the second register being very encouraging. Until June 1945 the Institute continued to provide secretarial and other facilities for the work of the National Service Committee for Social, Economic and Statistical Research, advisory to the Ministry of Labour. Inquiries completed for publication during the year and mentioned in the report include that of Prof. J. R. Hicks and Mrs. U. K. Hicks on the "Incidence of Local Rates in Great Britain", Prof. Sargant Florence's "Investment, Location and Size of Plant: an Inquiry into the Structure of Different Industries", and Dr. T. Balogh's "Studies in Financial Organisation".

Of major inquiries continued throughout the year, that on national expenditure, output and income, 1920-38, directed by Mr. Richard Stone, has resulted in two papers read to the Royal Statistical Society and an Occasional Paper, "Consumers' Expenditure in the United Kingdom, 1920-38; Interim Results and Analysis". The whole inquiry endeavours to present a consistent set of estimates of the components of the national expenditure, output and income over the period, and on the basis of this material to provide an economic analysis and interpretation of the changes which have taken place.

The investigations on the distribution of the product of industry under Dr. L. Rostas led to an Occasional Paper, "Productivity, Prices and Distribution in Selected British Industries". The ultimate purpose of the investigation is the analysts of the material collected to discover the dominant factors which determine distribution and prices in industry. Statistical investigations of prices, costs, distribution and productivity in different-sized units within selected industries have been made possible by the assistance of the Board of Trade. In the third major project, on the measurement of Colonial national incomes, Miss Deane is completing the work which can be undertaken in Britain and has prepared an Occasional Paper on the "Measurement of Colonial National Incomes : An Experiment". The next stage of the work will be a field study in Africa, for which purpose a Colonial research fellowship has been awarded to Miss Deane by the Colonial Office. Mr. R. Titmus's 